\title{
The Alternative Evaluation of Inter-city Railway in Regional Integrated Transport Corridor
}

\author{
Yuan-Li GU ${ }^{1, a,{ }^{*}}$, Xi SONG ${ }^{2, b}$ \\ ${ }^{1}$ MOE Key Laboratory for Transportation Complex Systems Theory and Theory and Technology, \\ Beijing Jiaotong University, Beijing, 100044, China \\ ${ }^{2}$ MOE Key Laboratory for Transportation Complex Systems Theory and Theory and Technology, \\ Beijing Jiaotong University, Beijing, 100044, China \\ aylgu@bjtu.edu.cn, b13125721@bjtu.edu.cn \\ ${ }^{*}$ Corresponding author
}

Keywords: The inter-city railway; Alternative evaluation; Index system; Discrete mutation - fuzzy matter-element method.

\begin{abstract}
First of all, Based on the analysis of traffic demand of inter-city channel and the function of the inter-city railway, the alternative evaluation system which include the factor of technical, economic and sustainable development is established. Then, the alternative evaluation method of inter-city railway in regional integrated transport corridor based on the fuzzy matter-element and discrete mutation is constructed. Finally, setting the chang-zhu-tan urban agglomeration as an example for analysis. The evaluation index system and evaluation method established in this paper has certain feasibility and practicability. And it has a certain guiding significance to promote the development of the inter-city railway and evaluation.
\end{abstract}

\section{Introduction}

With the economic globalization and regional integration, the development of the city is no longer confined to a single city, gradually formed in the central city as the core of urban agglomeration spatial units. The passenger transport demand between cities formed by the urban agglomeration economic ties has gradually come out, but conventional mode of transport can't load such traffic demand. Therefore, the planning and construction inter-city railway has become the urgent need of economic development.

The development of inter-city railway is also bound to have a certain impact, or a certain number of alternative on other mode of transportation in the regional integrated transport channels[1]. If we know the strength of the alternative, we can take measures to other corresponding measures on the mode of transportation. As a result, it has become a very critical and urgent issue to research how big is this alternative strength and how to evaluate alternative strength.

\section{The Alternative Evaluation of Inter-city Railway}

Index system. Analysis the influence factors of the inter-city railway alternative, to get the alternative evaluation indexes in the comprehensive transport .The indexes is divided into two categories, qualitative and quantitative[2]. As shown in table 1. 
Table 1 alternative evaluation index system

\begin{tabular}{|c|c|c|c|}
\hline \multirow{10}{*}{$\begin{array}{c}\text { The Alternative } \\
\text { Evaluation of Inter-city } \\
\text { Railway } \\
\text { in Regional Integrated } \\
\text { Transport corridor }\end{array}$} & Primary index layer & Secondary index layer & The index type \\
\hline & \multirow{3}{*}{ Social benefit indexes } & Comfort & Qualitative \\
\hline & & Economy & Quantitative \\
\hline & & Security & Quantitative \\
\hline & \multirow{3}{*}{ Technical indexes } & Rapidity & Quantitative \\
\hline & & Accessibility & Qualitative \\
\hline & & Punctuality & Qualitative \\
\hline & \multirow{3}{*}{ sustainable de velopment } & Occupation of land & Quantitative \\
\hline & & Environment pollution & Qualitative \\
\hline & & Development potential & Qualitative \\
\hline
\end{tabular}

This article set up the qualitative indexes which can be obtained by expert scoring or survey method.What's more , rapidity of quantitative indicators measured in time, economy reference fares[3], and security according to the set values in table 2; Occupation of land index as shown in table 3 .

Table 2 security index

\begin{tabular}{|c|c|c|c|}
\hline \multicolumn{4}{|c|}{ Accident death rate (deaths per billion passenger miles) } \\
\hline The inter-city railway & railway & Highway passenger & Private cars \\
\hline 0.1 & 0.1 & 0.2 & 2.6 \\
\hline
\end{tabular}

Table 3 Occupation of land index

\begin{tabular}{|c|c|c|}
\hline \multicolumn{3}{|c|}{ The occupation of land on Various modes of transport } \\
\hline The inter-city railway & Both the railway & highway \\
\hline 40 & 25 & 32 \\
\hline
\end{tabular}

Eevaluation method. Because involves index information has a certain ambiguity, this paper chooses fuzzy matter-element evaluation model to quantify the raw data processing[4]. In the calculation of weight, the discrete coefficient method is applied, which uses the mean square of each index of deviation to judge the discrete degree. Then, we can determine the weight of it. In addition, due to the size of the weight difference may be different levels of mutations in the evaluation index. So, the catastrophe theory is introduced for this sudden condition, to further improve the accuracy of the traditional fuzzy matter-element method.

\section{Set the changzhutan intercity railway as an example}

Calculation of evaluation indicators. The inter-city railway, railway, highway passenger transport and private cars is respectively set as M1, M2, M3, M4. Quantitative indicators are shown in table below[5]. As shown in table 4.

Table 4 Quantitative parameter values

\begin{tabular}{|c|c|c|c|c|}
\hline Quantitative indicators & $\begin{array}{c}\text { The inter-city } \\
\text { railway M1 }\end{array}$ & $\begin{array}{c}\text { Both the railway } \\
\text { M2 }\end{array}$ & $\begin{array}{c}\text { Highway } \\
\text { passenger M3 }\end{array}$ & $\begin{array}{c}\text { Private cars } \\
\text { M4 }\end{array}$ \\
\hline Rapidity C1 (unit: minutes) & 24 & 40 & 55 & 65 \\
\hline Economy C2 (unit: RMB) & 30 & 12 & 22 & 35 \\
\hline Security C3 & 0.1 & 0.1 & 0.2 & 2.6 \\
\hline Land C7 (unit: mu/km) & 40 & 25 & 32 & 32 \\
\hline
\end{tabular}

Combining with the analysis of the qualitative indexes, we adopt the method of investigation on the qualitative index score of each mode of transportation[6]. The investigation object are the passengers and private car owners. Survey sites are the railway station and long-distance bus terminal. Passengers score each transport mode and the evaluation results is shown in table 5: 
Table 5 qualitative index score values

\begin{tabular}{|c|c|c|c|c|}
\hline Qualitative indicators & $\begin{array}{c}\text { The inter-city } \\
\text { railway }\end{array}$ & Railway & $\begin{array}{c}\text { Highway } \\
\text { passenger }\end{array}$ & Private cars \\
\hline Comfort C4 & 9.3 & 4.5 & 8 & 9.5 \\
\hline Accessibility C5 & 8.3 & 8 & 8.5 & 9.5 \\
\hline Punctuality C6 & 9.3 & 4 & 7 & 9.5 \\
\hline Environmental pollution C8 & 7 & 6.5 & 5 & 4 \\
\hline Development potential C9 & 9.5 & 7.5 & 6.5 & 4 \\
\hline
\end{tabular}

The data processing of evaluation index. In this section, we will deal with the raw data of the four transport modes.

-Established the compound fuzzy matter-element.Based on the evaluation indexes of the original data, the compound fuzzy matter-element Rmn in table 6:

Table 6 The compound fuzzy matter-element Rmn

\begin{tabular}{|c|c|c|c|c|}
\hline $\mathrm{R}^{*}$ & $\mathrm{M} 1$ & $\mathrm{M} 2$ & $\mathrm{M} 3$ & $\mathrm{M} 4$ \\
\hline $\mathrm{C} 1$ & 24 & 40 & 55 & 65 \\
\hline $\mathrm{C} 2$ & 30 & 12 & 22 & 35 \\
\hline $\mathrm{C} 3$ & 0.1 & 0.1 & 0.2 & 2.6 \\
\hline $\mathrm{C} 4$ & 9.3 & 4.5 & 8 & 9.5 \\
\hline $\mathrm{C} 5$ & 8.3 & 8 & 8.5 & 9.5 \\
\hline $\mathrm{C} 6$ & 9.3 & 4 & 7 & 9.5 \\
\hline $\mathrm{C} 7$ & 40 & 25 & 32 & 32 \\
\hline $\mathrm{C} 9$ & 7 & 6.5 & 5 & 3.5 \\
\hline
\end{tabular}

-Establish optimal-membership compound fuzzy matter-element.With the dimensionless method processing data,we can get the optimal-membership compound fuzzy matter-element[7].

$U_{i j}=\left(x_{i j}-\min x_{i j}\right) /\left(\max x_{i j}-\min x_{i j} \cdot\right), \mathrm{i}=1,2, \ldots, \mathrm{m}, \mathrm{j}$ is the bigger the better;

$U_{i j}=\left(\max x_{i j}-x_{i j}\right) /\left(\max x_{i j}-\min x_{i j}\right), \mathrm{i}=1,2, \ldots, \mathrm{m}, \mathrm{j}$ is the smaller the better.

In the above formula, max $\mathrm{x}_{\mathrm{ij}}$ and $\min \mathrm{x}_{\mathrm{ij}}$ are respectively $\mathrm{j}$ th indicators of all the things. We can calculate the square of the difference of standard fuzzy matter-element and compound fuzzy matter-element. Then, difference square compound fuzzy matter-element is established. As shown in table 7 .

Table 7 difference square compound fuzzy matter-element $\mathrm{R}^{*}$

\begin{tabular}{|c|c|c|c|c|}
\hline $\mathrm{R}^{*}$ & M1 & M2 & M3 & M4 \\
\hline C1 & 0 & 0.1521 & 0.5776 & 1 \\
\hline C2 & 0.6084 & 0 & 0.1849 & 1 \\
\hline C3 4 & 0 & 0 & 0.0016 & 0 \\
\hline C5 & 0.0169 & 1 & 1 & 0 \\
\hline C6 & 0.64 & 1 & 0.4489 & 0 \\
\hline C7 & 0.0064 & 1 & 0.2209 & 0.2209 \\
\hline C8 & 1 & 0 & 0.3249 & 1 \\
\hline & 0 & 0.0196 & 0.3025 & 1 \\
\hline
\end{tabular}

Calculation of the weight. Use the formula of discrete coefficient method to calculate the weight[8]. As shown in formula (1),(2),(3),(4) The parameters of the calculation results are shown in table 8 below. 


$$
\begin{aligned}
& \bar{x}_{j}=\frac{1}{m} \sum_{i=1}^{m} x_{i j} \\
& \delta_{j}=\sqrt{\frac{1}{m} \sum_{i=1}^{m}\left(x_{i j}-\overline{x_{j}}\right)^{2}} \\
& D_{j}=\frac{\delta_{j}}{-} \\
& w_{j}=\frac{D_{j}}{\sum_{j=1}^{n} D_{j}}
\end{aligned}
$$

Table 8 parameters of calculation weight

\begin{tabular}{|c|c|c|c|c|}
\hline Evaluation indexes & Average & $\begin{array}{c}\text { Mean square } \\
\text { deviation }\end{array}$ & $\begin{array}{c}\text { Dispersion } \\
\text { coefficient }\end{array}$ & The whole weight \\
\hline Rapidity C1 & 46 & 15.5081 & 0.3371 & 0.0981 \\
\hline Economy C2 & 24.75 & 8.6999 & 0.3515 & 0.1023 \\
\hline Security C3 & 0.75 & 1.0689 & 1.4252 & 0.4149 \\
\hline Comfort C4 & 7.825 & 2.0042 & 0.2561 & 0.0746 \\
\hline Accessibility C5 & 8.575 & 0.5629 & 0.0656 & 0.0191 \\
\hline Punctuality C6 & 7.45 & 2.2209 & 0.2981 & 0.0868 \\
\hline land C7 & 32.25 & 5.3092 & 0.1646 & 0.0479 \\
\hline $\begin{array}{c}\text { Environmental } \\
\text { pollution C8 }\end{array}$ & 5.5 & 1.3693 & 0.2490 & 0.0725 \\
\hline $\begin{array}{c}\text { Development } \\
\text { potential C9 }\end{array}$ & 6.875 & 1.9804 & 0.2881 & 0.0839 \\
\hline
\end{tabular}

\begin{tabular}{|c|c|c|c|}
\hline The total target layer & Primary index layer & Secondary index layer & Local weights \\
\hline \multirow{9}{*}{$\begin{array}{l}\text { Evaluation of } \\
\text { alternative }\end{array}$} & \multirow{3}{*}{$\begin{array}{l}\text { Social benefit index } \\
\text { B1 }\end{array}$} & Comfort $\mathrm{C} 4$ & 0.1260 \\
\hline & & Economy C2 & 0.1729 \\
\hline & & Security C3 & 0.7011 \\
\hline & \multirow{3}{*}{ Technical index B2 } & Rapidity C1 & 0.4810 \\
\hline & & Accessibility C5 & 0.0937 \\
\hline & & Punctuality C6 & 0.4253 \\
\hline & \multirow{3}{*}{$\begin{array}{c}\text { Sustainable } \\
\text { development index B3 }\end{array}$} & Occupation of land C7 & 0.2346 \\
\hline & & Environmental pollution $\mathrm{C} 8$ & 0.3548 \\
\hline & & Development potential C9 & 0.4105 \\
\hline
\end{tabular}

On the basis of calculating the whole weight of each index, we can continue to calculate local weight of secondary index layer.As shown in table 9.

Table 9 calculation of local weight

Optimization of the mutations. By the structure of evaluation index system and mutation theory, there can be further optimization. Set the inter-city railway M1 as an example. The specific operation is as follows.

Optimization of Secondary index. Under the social benefit index B1 three secondary index of C4, $\mathrm{C} 2$ and $\mathrm{C} 3$ level dovetail mutations. The order of the weight and membership degree are $\mathrm{C} 4, \mathrm{C} 2$ and $\mathrm{C} 3$ accordly. So, $\mathrm{X}_{\mathrm{B} 1}$ is 0.1919 . Simultaneously, $\mathrm{X}_{\mathrm{B} 2}$ is $0.1628, \mathrm{X}_{\mathrm{B} 3}$ is 0.2346 . In a word, $\mathrm{X}_{\mathrm{B}}=\left[\mathrm{x}_{\mathrm{B} 1}, \mathrm{X}_{\mathrm{B} 2}, \mathrm{x}_{\mathrm{B} 3}\right]=[0.1919,0.1628,0.2346]$ 
Optimization of primary index. Through the Local weights of Secondary index cumulative, we can get the weights of primary index.It is $\mathrm{W}_{\mathrm{B}}=\left[\mathrm{W}_{\mathrm{B} 1}, \mathrm{~W}_{\mathrm{B} 2}, \mathrm{~W}_{\mathrm{B} 3}\right]=[0.5917,0.2040,0.2042]$. Two primary index constitute cusp catastrophe, and the result is $\mathrm{W}_{\mathrm{B} 1}>\mathrm{W}_{\mathrm{B} 3}>\mathrm{W}_{\mathrm{B} 2}$. The order of importance is $\mathrm{B} 1, \mathrm{~B} 3, \mathrm{~B} 2$ orderly. Accordingly, the cusp catastrophe membership is $\mathrm{X}_{\mathrm{B}}=\left[\mathrm{X}_{\mathrm{B} 1}, \mathrm{X}_{\mathrm{B} 3}, \mathrm{X}_{\mathrm{B} 2}\right]$. So, $\mathrm{D} 1$ is $\left[\mathrm{X}_{\mathrm{B} 1}, \mathrm{X}_{\mathrm{B} 3}, \mathrm{X}_{\mathrm{B} 2}\right]\left[\mathrm{W}_{\mathrm{B} 1}, \mathrm{~W}_{\mathrm{B} 3}, \mathrm{~W}_{\mathrm{B} 2}\right]=0.5147$.So,the membership of $\mathrm{M} 1$ (The inter-city railway) is 0.5147 .

Closeness degree. The formula of closeness degree is

$$
\rho H_{i}=1-\sqrt{d_{i}}
$$

$\mathrm{pH}_{\mathrm{i}}$ is the closeness degree of $\mathrm{i}$ th mode of transport, $\mathrm{d}_{\mathrm{i}}$ is membership of mutations.

Table 10 closeness degree and membership of mutations

\begin{tabular}{|c|c|c|c|c|}
\hline & M1 & M2 & M3 & M4 \\
\hline Membership of mutations di & 0.5147 & 0.5263 & 0.6693 & 0.8919 \\
\hline Closeness degree pHi & 0.2826 & 0.2745 & 0.1819 & 0.056 \\
\hline
\end{tabular}

\section{Conclusion}

By the discrete coefficient and the index weight mutation model is established, and we calculate the mutation optimization indexes at all levels. Then ,we get the closeness degree of the inter-city railway, railway, highway passenger, private cars are $0.2826,0.2745,0.1819$ and 0.056 orderly. Inter-city railway comprehensive rating score the highest in four kinds of transportation. This suggests that the intercity passenger channel in changsha-zhuzhou-xiangtan urban agglomeration has stronger alternative. In the process of raw data processing, optimal-membership of the calculation shows that the inter-city railway occupy obvious advantage in rapidity and security, also it has certain advantages in terms of comfort and punctuality. What's more, the environmental pollution is small and there is big development potential.

\section{Acknowledgements}

This work was financially supported from 'Science and Technology Program of Beijing,China (N o. Z121100000312101)' and 'Fundamental Research Funds for the Central Universities (No. 2011J BM244) '.

\section{References}

[1] Priemus H, Zonneveld W, What are Corridors and What are The Issues, Introduction to Special Issue: The Governance of Corridors, Journal of Transport Geography, Vol.3, 167-177, 2003.

[2] Z.F.Lu, The Alternative Evaluation of Inter-city Railway in Regional Integrated Transport corridor, Railway Transportation and Economy, Vol.12, 76-80,2012.

[3] J.Xie, Analysis of the Features of all kinds of Transportation in Regional Integrated Transport corridor's Transportation Features, Transportation enterprise management,Vol.1,57-59.2011

[4] A.U.Wu, G.Q.Xiao, K.X.Cai, Fuzzy evaluation of fire risk, Fire Science, Vol .2, 99-105,2004.

[5] Y.H.Li, The Function Orientation of the Inter-city Rail Transit, The Railway Survey, Vol .5, 10-12. 2007,

[6] Y.G.Zhao, Study of Reasonable Division of Passenger Transport way in Regional Channel inter-city, Railway Transportation and Economy, Vol. 4,67-73, 2012, 
[7] X.Q.Zhan, C.Liang, The Application of Fuzzy Matter-Element Model based on Entropy Weight in the Water Quality Comprehensive Evaluation, Journal of Water Conservancy, Vol.9,1057-1061,2005.

[8] Y.J.Pan, K.D.Liu, B.W.Zhang, Determination Method of Comprehensive Evaluation System of Objective Index Weight, Systems Engineering Theory and Practice, Vol.8,37-42, 2001. 